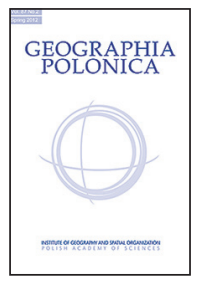 \\ INSTITUTE OF GEOGRAPHY AND SPATIAL ORGANIZATION \\ POLISH ACADEMY OF SCIENCES \\ www.igipz.pan.pl \\ www.geographiapolonica.pl
}

\title{
TRANSFORMATIONS OF LARGE HOUSING ESTATES IN POST-SOCIALIST CITY: THE CASE OF ŁÓDŹ, POLAND
}

\author{
Ewa Szafrańska \\ Faculty of Geographical Sciences \\ University of Łódź \\ Kopcińskiego 31, 90-142 Łódź: Poland \\ e-mail: e_szafran@geo.uni.lodz.pl
}

\begin{abstract}
The main purpose of this paper is to identify ongoing changes in post-socialist large housing estates and to clarify their main factors, using a case study approach. The paper examines the transformations of nine housing estates in the third largest Polish city - Łódź. The transformations were analysed in two dimensions: social (socio-demographic changes) and physical (changes in the spatial and functional structure and changes in the physiognomy). The key question was whether the changes occurring in large housing estates in Łódź protect them before the development of the social and physical degradation, identified in many estates in Western Europe, referred as the "large housing estate syndrome". Research has shown that in examined housing estates there are no symptoms of physical or social degradation. Moreover, processes found there contribute to the prevention of the negative phenomena leading to the development of the "large housing estate syndrome".
\end{abstract}

\section{Key words}

housing transformation $\cdot$ large housing estates $\cdot$ post-socialist city $•$ Łódź

\section{Introduction}

Large housing estates built after the Second World War are present nearly in all European cities, however systemic and political factors decided that they developed on the largest scale in socialist countries. Nowadays, in many East Central European countries large postwar housing estates constitute the dominant form of urban residential environment and a significant part of the housing market.
According to data obtained by the IRS (Institute for Regional Development and Structural Planning) in the countries of the former Eastern Bloc, approximately 170 million people lived in large housing estates in the 1990s, while excluding the countries of the former USSR approximately 34 million (Knorr-Siedow 1996). In contemporary Poland, large post-war housing estates, according to different estimates, are inhabited by over eight million (Węcławowicz 2007), more than half 
of the urban population (Rębowska 2000), and approximately $56 \%$ of all households (Rembarz 2010). The number of dwellings in large housing estates in post-socialist Polish cities is estimated at about 3.5 million (Rębowska et al. 2006). According to Knorr-Siedow (1996), the proportion of flats in large housing estates (defined as prefabricated estates with over 2500 flats) in the total number of flats in Central and Eastern Europe in 1990 was on average 29\%, and reached its highest in the former Czechoslovakia (56\%) and Poland (35\%). In West European countries the percentage of flats in these estates, as a proportion of total housing resources, was estimated at about 3-7\% (Kovács 1999). As reported by Rembarz (2010), large housing estates in the eastern part of Germany in the mid-1990s were inhabited by every fourth citizen, while in the western - by every sixtieth.

In socialist cities, large housing estates were seen as instruments of social transformation and an improvement in living conditions, especially for the working class (Wectawowicz et al. 2005). Moreover, the idea of collective and uniform housing was perfectly fitted to state-socialist politics and made it possible to achieve the ideological goal which was a mix of different social groups, in accordance with the idea of egalitarianism (Kovács et al. 2010). Hence, the era of the construction of large housing estates in socialist countries lasted until the collapse of socialism in the end of 1980s, while in most Western European countries it ended in the late 1970s. The symbolic date of the fall of the modernist philosophy behind the idea of such estates is 1972, when the Pruitt-lgoe estate in the USA, consisting of a complex of 14-storey buildings, was demolished due to the lack of people willing to settle there (Jencks 1977).

The socialist estates were built hastily and negligently in order to satisfy growing residential needs caused by rapid socialist urbanization and industrialization in cities. The designers of these residential complexes, whose architectural form was determined only by functional requirements, did not think of any particular group of users, nor did they consider their housing needs or aspirations. The numerous drawbacks of these estates, such as monotonous architecture, poor aesthetics, small living areas in the flats and their low quality and functionality, as well as insufficient social and service infrastructure and the poor quality of public spaces, did not make a friendly housing environment. However, during the socialist period, moving to a new block of flats in a new housing estate, was usually the only chance to improve one's living conditions (Węcławowicz 2007). In Poland, the strong structural deficit on the housing market (resulting from dynamic urbanization), the progressive degradation of pre-war housing resources, limitations put on private construction, as well as low incomes (and relatively modest residential aspirations), created a reality in which living in a block of flats was a dream for the majority of Poles, regardless of their social status (Lewicka 2004).

The political and economic transformation from socialism to post-socialism brought significant socio-economic changes and consequently an alteration in the position of large housing estates on the local housing market. Due to the transformation, housing supply and demand in post-socialist cities has substantially changed. The appearance of new forms of housing, such as gated communities and residential parks, as well as the processes of suburbanization and revitalization of the inner city, created a challenge for large housing estates and started to endanger their position (Borén \& Gentile 2007; Kovács \& Herfert 2012). As a result of the emergence of new forms of housing, and an increase in socioeconomic disparities, as well as changes in the housing aspirations of many inhabitants and growth in their purchasing power, in many post-socialist cities the residential prestige of such estates rapidly decreased. However, a closer look at post-socialist housing estates reveals that during the transition from state socialist to post-socialist conditions, their development trajectories varied between countries, regions, cities and even within city space (Temelová et al. 2011, Kovács 
\& Herfert 2012). This observation constitutes an important challenge for further research into different geographical scales: country, city, and even particular estates.

The purpose of this article is to identify the ongoing changes in large housing estates in the post-socialist city and to clarify their main factors, using a case study approach.

\section{Background}

In several European countries, the definition of a large housing estate is a specific legal category introduced in order to facilitate the realization of a spatial policy oriented towards transforming these areas and preventing the large housing estate syndrome. In Germany, the legal category of Großsiedlung is for estates with at least 2500 flats (Wassenberg et al. 2004), while in France the Grand Ensemble status is given to housing areas with over 2000 flats within Greater Paris and over 1000 flats on the outskirts of the city (Coudroy de Lille 2000; Rembarz 2010).

In Poland there is no one definition of this particular urban form, but numerous authors use the definition, formulated for the purposes of the RESTATE 1 project (Węcławowicz et al. 2005; Górczyńska 2008). According to the RESTATE definition, large housing estates constitute spatially isolated groups of buildings, comprising over 2000 flats, built in the second half of the 20th century, planned and fully or partly financed by the state (Musterd \& van Kempen 2005). According to other authors (Knorr-Siedow 1996) large housing estates are defined as estates constructed using prefabricated technology with over 2500 flats.

Large post-war prefabricated housing estates were built all over Europe. However, despite similar physiognomy, the estates built in socialist countries were different from those found in Western Europe. They differed

\footnotetext{
1 RESTATE - the acronym of the international research project Restructuring Large-scale Housing Estates in European Cities, 2005.
}

primarily due to the urban planning scale and role on the local housing market, as well as the socio-economic profile of the inhabitants, and as a consequence their position in the ecological structure of the city (Coudroy de Lille 2000; Turkington et al. 2004; Musterd \& van Kempen 2005; Dekker et al. 2005, 2007; Sykora 2009; Kovács \& Herfert 2012). Differently to Western Europe, in socialist countries large housing estates were attractive not only for blue collar workers and for middle class families, but even for representatives of the socialist elite (Szelényi \& Konrád 1969)

After the political and economic transformation, in the 1990s, large housing estates in post-socialist cities have been classified by many authors as problem areas under threat of becoming slums, 'the escape' areas, devoid of community ties or sense of attachment to territory, areas affected by physical and social degradation (Jałowiecki 1995; Szelény 1996; Enyedi 1998; Czepczyński 1999; Gaczek \& Rykiel 1999; Rykiel 1999)². According to Enyedi (1998) "the rapid decline of housing estates into slums represents the 'time bomb' of urban development, a possible source of a grave urban crisis". However, this negative image of such estates as a housing environment of low social, architectonic, aesthetic and symbolic values is not always confirmed by empirical studies (Musterd \& van Kempen 2005; Bernt 2007; Dekker et al. 2007, 2011; Grossmann \& Haase 2011). On the other hand, as reported Kovács and Herfert (2012), the large housing estates in post-socialist countries are exposed to a slow decline of their social status. However, as they note this process is not homogeneous, its speed and dimension depends very much on local conditions and the functioning of the housing market.

\footnotetext{
2 The bad image of this type of building, which has been present not only in literature, but in common awareness and in media discourse since the 1990, has probably resulted from the projection of the situation in West European countries, where many such estates have become areas of social exclusion, ghettos, areas inhabited by immigrants and those from the lowest level of the social structure.
} 
In Poland, as noted by numerous authors, large housing estates have not turned into problem areas (Węcławowicz et al. 2003, 2005; Kozłowski 2005; Kotus 2006; Gorczyca 2009; Warchalska-Troll 2012; Szafrańska 2012a, 2013). Contemporary studies show that over a dozen years after the transformation, such housing estates are frequently inhabited by people with relatively high socio-economic status and despite the outflow of more well-off residents, their ecological position is not decreasing (Zborowski 2005; Marcińczak 2007; Szafrańska 2011). Due to their prevalence living in large housing estates is not seen as socially degrading (Borowik 2003; Szafrańska 2009). Moreover, most inhabitants of these estates have a high level of residential satisfaction (Górczyńska 2008; Szafrańska 2009). Also a study of preferred places of residence puts such estates quite high in the hierarchy of residential areas in the city (Groeger 2004).

One of the most important question, discussed in literature is the future of large housing estates in post-socialist cities. Based on research carried out in the Czech Republic, Temelová et al. (2011) identified three distinct development scenarios for housing estates: (1) estates with positive prospects for future development thanks to the mixed socio-economic composition of the population and the improving physical condition of the residential environment, (2) estates on the crossroads between regeneration and degradation, and (3) estates with a concentration of social problems and little chance of improvement. Wassenberg, Tarkington and van Kempen (2004) pointed out that factors influencing the future position of large housing estates on local housing markets operate on two levels: macro and micro. At the macro level, these authors identified two main factors: public policies and global megatrends, such as technological, economical, political, demographic, socio-cultural and environmental trends. At the micro level, the position of a single estate on the housing market will be determined according to the inter-relationship between supply and demand. To the key factors operating at the supply side belong: number and character of housing stock environment, quality of dwellings and the estate, use and development of dwellings and estate, while on the demand side: the number and differentiation of households, their resources and constraints, and their preferences.

According to the model of the transformational processes of urban space in postsocialist cities developed by Matlovič and Sedláková (2007), in the housing estates zone processes of revitalisation, commercialisation, sacralisation, segregation and downgrading of social-economic status are found. Other processes occurring in large housing estates are defined as modernization, humanization, rehabilitation or renovation (Chmielewski \& Mirecka 2001). Some of these changes are the result of market processes taking place after the economic and political transition in the post-socialist urban space; others have been planned to achieve improvements in living conditions in these estates.

The main aim of this article is to analyze transformations in large post-socialist housing estates and to clarify their main factors. The paper examines the transformations of the nine largest housing estates in one selected large Polish city - the city of Łódź. These transformations were analysed in two dimensions: social (socio-demographic changes) and physical (changes in the spatial and functional structure and changes in physiognomy). The key question is whether the processes occurring in large housing estates in Łódź will protect them before negative phenomena of social and physical degradation develop, in the literature referred as the 'large housing estate syndrome' (Rembarz 2010) or 'spiral of decline' (Murie et al. 2003). The 'large housing estate syndrome' was a phenomenon recognized in Western Europe in the 1980s and defined as a complex of spatial-social conditions, producing a negative image of an estate and accelerating the downward spiral and the replacement of the culturally stronger inhabitants 
by weaker ones. It leads to an increase in the number of vacant flats and structural social problems, intensifying the spatial degradation. This in turn causes the economic potential of the estate (such as the purchasing power or the market value of the housing resources) to disappear (Rembarz 2010). The 'spiral of decline' may be increased because more stable and affluent households move away or because there are no opportunities for deprived households to move away (Murie et al. 2003).

Methodologically, the paper is based on case study research which illustrates situations in three types of housing estates within one of the largest Polish cities, distinguished on the basis of the period of their construction. Analysis of changes in the social structure of inhabitants is based on statistical data collected during the National Censuses in 1988 and 2002, on unpublished data from the Statistical Office as well as on information obtained during interviews with employees of the housing cooperatives which administer the estates. The changes which took place in the spatial and functional structure of examined areas and in their physiognomy were identified by field research (observation and inventory).

This paper also presents the results of a qualitative questionnaire survey conducted among the inhabitants of new infill buildings located in the area of research, erected after the change of political system, in the later 1990s or later. The survey was conducted in four new residential buildings (including two gated ones), built in 1997, 2001, 2003 and 2005, situated in the two largest housing estates in Łódź: Widzew-Wschód and Retkinia. The survey was based on purposive sampling, and the technique used was the semi-structured interview. The list of questions concerned the social status and the occupation of the respondents, as well as selected aspects of estate evaluation. Due to the difficult access to the respondents, the study was conducted on only a small sample of 52 persons. The survey was done in the first half of 2012.

\section{Large housing estates in Łódź: characteristics of the research area}

Łódź is the third largest city in Poland, with a population of 718,900 (2012). It is situated in the central part of the country. During the socialist period, Łódź was the largest centre of the Polish textile industry with a growing population but since 1989 population decline has started. During the last 25 years, the city has lost over 130,000 inhabitants (i.e. 15\% of population). This decrease was caused by two reasons: firstly by natural population decline, secondly by negative net migration. In 2010 there were 339,500 dwellings in the city, over a half of which were in prefabricated multi-family buildings, not all, however, were part of large housing estates. According to the definition adopted for the purpose of these studies, compiled from the Knorr-Siedow (1996) and RESTATE (2005) definitions, the large housing estates in Łódź are occupied by more than 350,000 people, i.e. approximately a half of the city's population.

The first post-war housing estates using prefabricated elements were built in Łódź at the turn of the 1950s and 1960s (Doły, Koziny and the largest - Żubardź). In the 1960s ongoing investment projects were continued, and the construction of new large estates (Teofilów, Dąrowa, and Zarzew) were launched. Except for Teofilów, they are located on land lying within the railway ring and within this concentric configuration they encircle the city centre. The city's largest housing estates (Retkinia and Widzew-Wschód) were built in the 1970s and 1980s. In the 1980s the construction of new estates - Chojny Zatorze, Radogoszcz and Olechów - was launched. The estates which developed in the last two decades of real socialism constituted large housing districts spatially separated from the historical urban core of Łódź. Their spatial layout is wedgeshaped and spreads along the city's major communication routes, along the East-West axis (Retkinia-Olechów) and the North-South axis (Radogoszcz- Chojny Zatorze) (Fig. 1). 


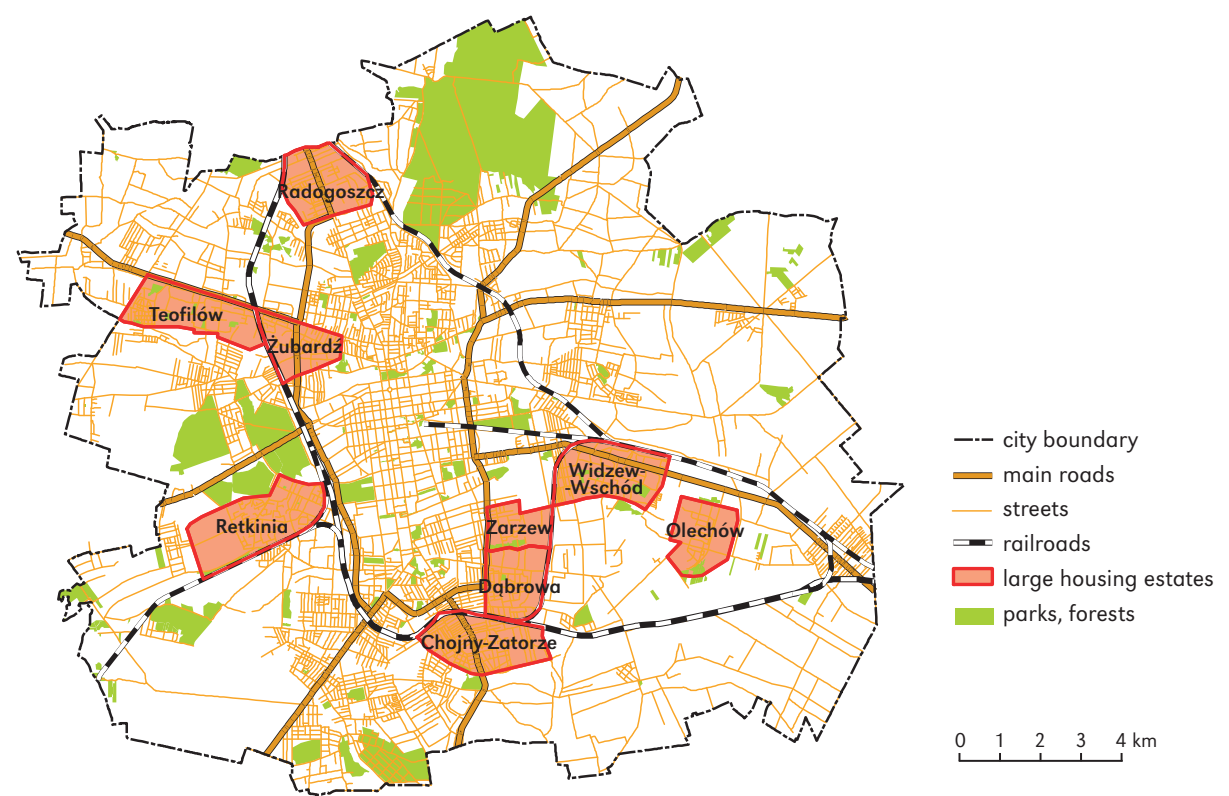

Figure 1. Large housing estates in the Łódź area

The study included the nine largest housing estates grouped into three types distinguished on the basis of their periods of construction, and as a consequence in terms of the size of the dwellings they offer. Type 1 includes the oldest estates built in the 1960s and early 1970s, characterised by high proportions of small dwellings with unimpressive average floor space: Żubardź, Dabrowa, Teofilów, and Zarzew; type 2 - estates built in the second half of the 1970s and in the 1980s, characterised by a smaller proportion of small dwellings and larger average floor spaces: Retkinia and Widzew-Wschód; type 3 - the newest built in the 1980s, with the largest average floor spaces: Chojny-Zatorze, Radogoszcz, and the still expanding Olechów.

According the National Census 2002 - the last which contains a wide range of detailed data specific to particular areas - the types of estates under analysis also differed in terms of the socio-demographic structure of the inhabitants. These differences were also a consequence of the period of their construction. The oldest estates (type 1) were characterised by an age structure with a significant percentage aged 60 and older and a low share of those below 19 , high proportions of single-person households, and a low proportions of active earners. Estates built in the second half of the 1970s and in the 1980s (type 2) were characterised by a younger age structure, more balanced household structure and higher shares of 3and 4-person households, higher proportions of active earners, and a higher social status of their inhabitants (measured by their educational background). The newest estates (type 3) had the youngest age structure, the highest proportions of active earners, the lowest percentage of single-person households, and the highest proportion with higher education (Tab. 1).

\section{The social dimension of the transformation}

The transformation of the social (socio-demographic) structure of large housing estates is based on statistical data collected during the National Censuses in 1988 and 2002 and on unpublished data, which includes 
Table 1. The size of dwellings and the socio-demographic structure of population in large housing estates in Łódź (in 2002)

\begin{tabular}{|c|c|c|c|c|c|c|c|c|}
\hline \multirow[b]{2}{*}{$\begin{array}{c}\text { Estates } \\
\text { by the period } \\
\text { of construction }\end{array}$} & \multirow[b]{2}{*}{$\begin{array}{l}\text { Share } \\
\text { of dwell- } \\
\text { ings (up } \\
\text { to } 39 \mathrm{~m}^{2} \text { ) }\end{array}$} & \multirow[b]{2}{*}{$\begin{array}{l}\text { Avera- } \\
\text { ge size of } \\
\text { dwellings } \\
\left.\text { [in } \mathrm{m}^{2}\right]\end{array}$} & \multirow[b]{2}{*}{$\begin{array}{c}\text { Share } \\
\text { of single- } \\
\text { person } \\
\text { house- } \\
\text { holds }\end{array}$} & \multicolumn{5}{|c|}{ Share of inhabitants } \\
\hline & & & & $\begin{array}{l}\text { aged } \\
0-19\end{array}$ & $\begin{array}{c}\text { aged } \\
60+\end{array}$ & $\begin{array}{c}\text { with } \\
\text { at least } \\
\text { secondary } \\
\text { education }\end{array}$ & $\begin{array}{l}\text { with higher } \\
\text { education }\end{array}$ & $\begin{array}{l}\text { with em- } \\
\text { ployment } \\
\text { as a source } \\
\text { of income }\end{array}$ \\
\hline \multicolumn{9}{|c|}{ Estates built in the 1960s and the first half of the 1970 s } \\
\hline Żubardź & 39.2 & 42.9 & 41.7 & 16.2 & 30.7 & 55.0 & 15.2 & 50.8 \\
\hline Dąbrowa & 54.8 & 41.2 & 36.7 & 16.3 & 33.9 & 45.5 & 8.8 & 46.6 \\
\hline Teofilów & 48.8 & 46.6 & 38.3 & 15.0 & 32.9 & 54.8 & 14.9 & 48.7 \\
\hline Zarzew & 41.1 & 44.3 & 37.3 & 16.5 & 26.3 & 53.6 & 14.2 & 51.7 \\
\hline \multicolumn{9}{|c|}{ Estates built in the second half of the 1970 s and early 1980 s } \\
\hline Retkinia & 16.9 & 51.9 & 33.0 & 15.7 & 19.4 & 63.1 & 18.9 & 59.3 \\
\hline $\begin{array}{l}\text { Widzew- } \\
\text {-Wschód }\end{array}$ & 12.8 & 52.5 & 25.5 & 17.5 & 12.5 & 59.3 & 14.8 & 64.6 \\
\hline \multicolumn{9}{|c|}{ Estates built in the 1980 s } \\
\hline $\begin{array}{l}\text { Chojny- } \\
\text {-Zatorze }\end{array}$ & 16.0 & 56.5 & 25.1 & 21.0 & 11.4 & 54.1 & 12.6 & 67.9 \\
\hline Radogoszcz & 9.5 & 70.9 & 23.5 & 21.2 & 12.3 & 62.9 & 20.9 & 68.9 \\
\hline Olechów & 8.3 & 62.1 & 18.1 & 25.1 & 6.3 & 60.8 & 17.5 & 78.1 \\
\hline Łódź (average) & 32.2 & 52.0 & 35.4 & 19.2 & 21.1 & 53.0 & 14.2 & 57.2 \\
\hline
\end{tabular}

Source: based on the National Census 2002 data.

2010, collected by the Statistical Office in Łódź.

The analysis of data collected in 1988 and 2002 showed that in the social structure of large housing estates in Łódź in the first period of transformation (1988-2002), the following changes occurred (Tab. 2):

- population decrease, highest in the older estates built in the 1960s, 1970s and the first half of the 1980s, while in newest estates - a population increase,

- increase in the number of dwellings - the larger in the newer estates,

- significant increase of the share of singleperson households - in all types of estates,

- decline in the share of the youngest population - strongest in estates from the '70s,

- improvement in the educational structure of inhabitants - in all types of estates,

- significant ageing of the population in the estates built in the 1960s and 1970s.

The newest statistical data collected by Statistical Office in Łódź, which relates to large housing estates, contains only the number of dwellings, the number of inhabitants and the age structure of population confirmed the processes listed above. In all examined estates (except for Olechów), depopulation and ageing has deepened (Tab. 3). In all estates the number of dwellings has slightly increased.

The transformation of the social (socio-demographic) structure of large housing estates, as well as in other areas of the city, takes place as a result of natural demographic processes and migration. This is difficult to analyse in detail due to the limited availability of data on the number and structure of migrants on the small scale of the particular estates. However, regular studies conducted by the author in the large housing estates in Łódź (observations, surveys conducted among the residents and at housing cooperatives, the analysis of incomplete statistical data; see Szafrańska 2009, 2011, 2012a, 2013), showed that among the migration 
Table 2. Changes in the number of dwellings, and in the socio-demographic structure of population in large housing estates in Łódź: 1988-2002

\begin{tabular}{|c|c|c|c|c|c|c|}
\hline \multirow{4}{*}{$\begin{array}{c}\text { Estates } \\
\text { by the period } \\
\text { of construction }\end{array}$} & \multicolumn{6}{|c|}{ Changes in } \\
\hline & \multicolumn{2}{|c|}{ number of } & \multicolumn{2}{|c|}{ share of inhabitants by age } & \multirow{2}{*}{$\begin{array}{c}\text { share } \\
\text { of inhabitants } \\
\text { with higher } \\
\text { education }\end{array}$} & \multirow{2}{*}{$\begin{array}{l}\text { share of sin- } \\
\text { gle-person } \\
\text { households }\end{array}$} \\
\hline & inhabitants & dwellings & $0-19$ & $60+$ & & \\
\hline & \multicolumn{6}{|c|}{$1988=100$} \\
\hline \multicolumn{7}{|c|}{ Estates built in the 1960s and the first half of the 1970 s } \\
\hline Żubardź & 83.9 & 99.7 & 79.1 & 139.7 & 121.6 & 162.1 \\
\hline Dąbrowa & 84.8 & 100.6 & 87.8 & 159.6 & 151.7 & 174.0 \\
\hline Teofilów & 86.5 & 103.1 & 78.2 & 176.4 & 161.7 & 177.5 \\
\hline Zarzew & 87.2 & 103.3 & 69.8 & 154.4 & 157.8 & 161.7 \\
\hline \multicolumn{7}{|c|}{ Estates built in the second half of the 1970 s and early 1980 s } \\
\hline Retkinia & 89.9 & 106.1 & 54.5 & 154.8 & 141.0 & 177.3 \\
\hline Widzew-Wschód & 95.6 & 111.7 & 51.4 & 143.9 & 143.4 & 185.5 \\
\hline \multicolumn{7}{|c|}{ Estates built in the $1980 \mathrm{~s}$} \\
\hline Chojny-Zatorze & 102.8 & 113.8 & 63.1 & 107.2 & 135.0 & 139.8 \\
\hline Radogoszcz & 113.9 & 128.0 & 64.0 & 106.4 & 136.7 & 144.3 \\
\hline Olechów* & 543.9 & 636.3 & 74.3 & 71.8 & 282.9 & 136.8 \\
\hline Łódź(average) & 92.4 & 104.6 & 77.4 & 110.5 & 138.3 & 136.6 \\
\hline
\end{tabular}

Source: based on the National Censuses 1988 and 2002 data.

* Olechów differs from other housing estates because in the period 1988-2002 it was significantly expanded by property developers and widened its boundaries. Other estates were analyzed in the same boundaries in 1988 and 2002.

Table 3. Changes in the number of dwellings, number of inhabitants and the age structure of population in large housing estates in Łódź: 2002-2010

\begin{tabular}{|c|c|c|c|c|}
\hline \multirow{4}{*}{$\begin{array}{c}\text { Estates } \\
\text { by the period } \\
\text { of construction }\end{array}$} & \multicolumn{4}{|c|}{ Changes in } \\
\hline & \multicolumn{2}{|c|}{ number of } & \multicolumn{2}{|c|}{ share of inhabitants by age } \\
\hline & inhabitants & dwellings & $0-17$ & $60 / 65+$ \\
\hline & \multicolumn{4}{|c|}{$2002=100$} \\
\hline \multicolumn{5}{|c|}{ Estates built in the 1960s and the first half of the 1970 s } \\
\hline Żubardź & 91.3 & 100.8 & 85.7 & 108.2 \\
\hline Dąbrowa & 91.1 & 100.7 & 87.9 & 105.4 \\
\hline Teofilów & 91.3 & 101.2 & 94.6 & 117.5 \\
\hline Zarzew & 96.7 & 102.3 & 85.5 & 144.5 \\
\hline \multicolumn{5}{|c|}{ Estates built in the second half of the 1970 s and early 1980 s } \\
\hline Retkinia & 92.5 & 101.3 & 86.1 & 112.1 \\
\hline Widzew-Wschód & 92.9 & 101.4 & 77.0 & 136.4 \\
\hline \multicolumn{5}{|c|}{ Estates built in the $1980 \mathrm{~s}$} \\
\hline Chojny-Zatorze & 94.0 & 101.1 & 90.8 & 103.2 \\
\hline Radogoszcz & 94.7 & 102.6 & 74.1 & 124.6 \\
\hline Olechów & 111.8 & 121.6 & 89.9 & 135.4 \\
\hline Łódź(average) & 93.4 & 101.7 & 87.0 & 130.6 \\
\hline
\end{tabular}

Source: based on the National Census 2002 data and unpublished materials from the Statistical Office of Poland. 
processes that contribute to the socio-demographic changes in the population of these estates the most important are:

- an inflow of inhabitants who have bought their flats on the secondary real estate market, and whose socio-economic status is higher than that of the 'old' primary residents;

- an inflow of young people with differing economic status who inherit the flats (generation exchange) - mainly in the older estates;

- an inflow of inhabitants who have bought their flats on the primary real estate market (in new buildings supplementing 'old' ones) whose socio-economic status is significantly higher than that of the primary residents;

- an outflow of residents with relatively high socio-economic status and high aspirations as regards housing to other parts of the city (usually to the suburbs, but also to the revitalized tenement houses in the city centre or to modern apartments at various locations);

- an outflow of young inhabitants caused by the fact that many households entering the stage of family life cycle called the 'empty nest' phase which starts when adult children leave home - mainly in the newer estates from the 1980s and early 1990s;

- an outflow of residents with a very low socio-economic status whose financial situation does not allow them to keep their flats (usually to tenement houses of a lower standard or smaller flats in different types of multi-family housing and at different locations) - they are usually descendants of the first inhabitants of the estate who had been allocated flats before 1989 .

One of the most important processes which contributes to the improvement of the population structure of large housing estates (as regards age and social status) is the inflow of new inhabitants who purchase flats on the secondary real estate market (in 'old' blocks of flats). Its scale depends on the time when the estate was built. The older the estate, the stronger the rotation of its inhab- itants. Surveys conducted at the housing cooperatives of $Ł o ́ d z ́$ estates show that in those built at the turn of the 1980s - about 30\%, and in the estates from the 1960s, in some blocks of flats - up to as many as $40 \%$ of the inhabitants - are the owners of new flats who bought these on the secondary market. They are usually from the generation of 30-yearolds who have set up their first own homes and by buying a flat in a housing estate (relatively affordable and the relation of its price to its standard is relatively favourable) they have begun their own, adult 'housing biography', treating such a flat as temporary or target, depending on the economic condition of the household. It goes without saying that the socio-economic status of these people is also higher ${ }^{3}$ than the average status of the previous inhabitants (though not as high as of the owners of new flats).

Another process, which occurs in the older estates built in the 1960s and 1970s, is the process of generation exchange. The generation of grandparents (the first owners of flats) is replaced by the generation of grandchildren. Despite the imperfect form of ownership, which gives only a limited right to the property ${ }^{4}$, the flats are inherited. The exchange mainly contributes to the demographic rejuvenation of the estates, and to a smaller degree - to an improvement of the socio-economic status of the inhabitants.

The next important process which strongly influences the inflow of those with a higher social status, and improves both the social and physical structure of the examined estates, is the appearance of new individual multi-family buildings or small complexes,

\footnotetext{
3 The prices of flats on the secondary real estate market depend on the age of the building and its standard as well as the localisation within the city space. In Łódź, they are on average 3877 PLN, while in Warsaw 8390 PLN (November, 2013) (http://www.bankier. pl/wiadomosc/Ceny-mieszkan-listopad-2013-3007384. html).

4 In Poland usually members of cooperative are the owners of flats, but they are not the owners of appropriate part of property. Despite of the limits, this type of the right on property is transferable and hereditary.
} 
built after 1990 within the existing estates. Their construction technology differs from that of the surrounding buildings - they are not 'prefabricated concrete panel' houses (Figs. 2-5). Their standard of finish is higher and the physiognomy is different (architectural details, elements of small architecture, the colour and shape of the buildings). Some of the new developments are built as gated communities which bears the hallmarks of appropriating public space and is a negative phenomenon, considering the continuity and accessibility of this space.

In order to portray the social dimension of the process discussed here, we should establish who the residents of the new blocks of flats are. The relatively high socio-economic status of the new residents is proved by their purchasing power - they have sufficient financial resources (or creditworthiness), which enables them to buy a flat on the primary market. Although the prices of new flats in Łódź are the lowest among large Polish cities, considering the relatively low purchasing power of Łódź inhabitants, buying a flat on the primary market is the same as in the whole country. The average price of one $\mathrm{m}^{2}$ of a new flat in Łódź in November 2013 was over $1.5 x$ the average gross salary in the city (5030 PLN compared to 3344 PLN) ${ }^{5}$.

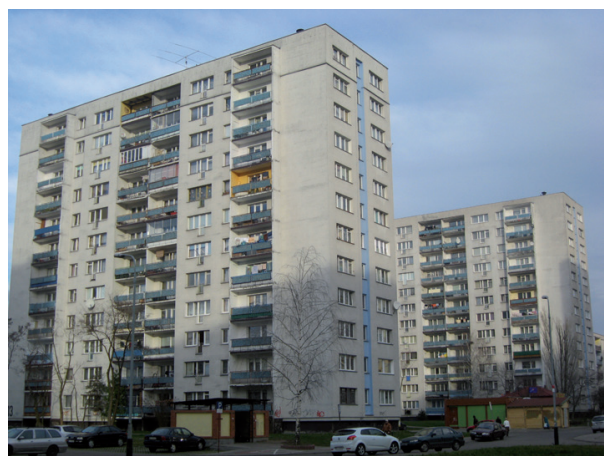

Figure 2. Typical 11-storeys residential buildings (built in 1970s) in the Retkinia estate in Łódź

5 http://www.bankier.pl/wiadomosc/Ceny-mieszkan-listopad-2013-3007384.html.

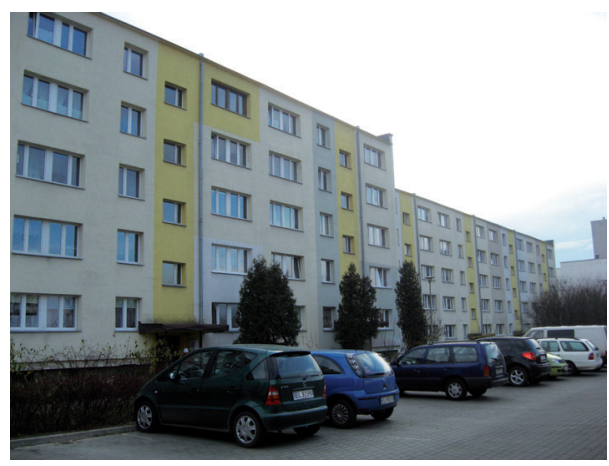

Figure 3. Typical 5-storeys residential buildings (built in 1970s) in the Retkinia estate in Łódź

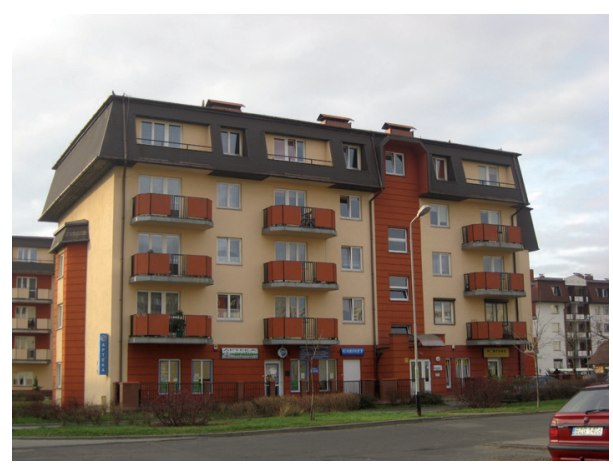

Figure 4. New residential building (built in end of 1990s) in the Retkinia estate in Łódź

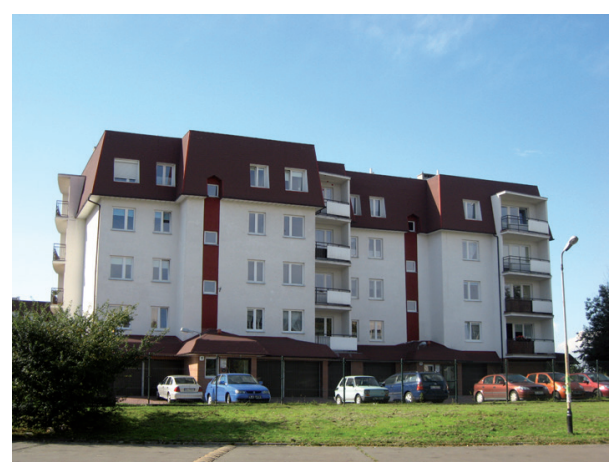

Figure 5. New residential building (built in end of 1990s) in the Widzew-Wschód estate in Łódź

The survey conducted among the inhabitants of selected new blocks of flats showed that they are mainly: 
- specialists in professions which require higher education and included four with doctorates (doctors, teachers, computer programmers, pharmacists, officials, employees of financial institutions and insurance companies) and entrepreneurs, owners of small companies working mostly in the service sector (computer technology, design, decoration and construction, law, insurance). They are social categories (representatives of occupational groups), which in the still crystallizing and constantly recomposed social stratification in post-socialist Poland, may be defined as middle class;

- people with high occupational activity nearly all the respondents who were not retired declared that they were professionally active, those who did not work were only mothers caring for young children;

- those who at the moment of purchasing new flats were 30-40 years old (today they are 35-45);

- families with children (mostly one or two, in two cases with three), rarely childless couples (young or at the 'empty nest' phase), as well as singles (women rather than men);

- flat owners (only three flats were being rented) who declared that their housing needs were relatively satisfied and they were happy with their present accommodation, as well as their unwillingness to migrate;

- those for whom the present flat is not their first (earlier they owned or rented flats in older blocks, rarely lived in tenement or one-family houses);

- those who appreciate comfort, safety (in gated buildings), the relatively high standard of dwellings, neighbours of a similar status, the advantage of living close to the city centre and on the outskirts at the same time (surrounded by greenery and open spaces), the favourable relation of price to the standard of the flat. The disadvantages (mentioned rarely, mainly by the inhabitants of unfenced buildings) included a lack of parking places (in buildings without garages), neglected surroundings and a relatively weak sense of security.

The social composition of the residents of new buildings leads to the creation of enclaves with a much higher socio-economic status than that of the surrounding area. This process strongly influences the inflow of those with a higher status, and in consequence, improves the social status of these estates and their position in the ecological structure of the city.

On the other hand, this phenomenon has negative consequences. Introducing new buildings into the spatial structure of the estates, especially gated areas, causes fragmentation and the appropriation of public space and leads to social segregation. According to the questionnaire survey conducted in one of the large housing estates (Szafrańska 2009), the neighbourhood of gated communities evokes frustration and a sense of occupying an inferior position among neighbouring residents.

Due to the fact that new housing developments with a higher standard and diversified architecture attract inflows of younger inhabitants and those with a higher status than the existing population, this situation may also be defined as the 'gentrification' of large housing estates (Szafrańska 2012b).

\section{The physical dimension of the transformation}

Apart from the transformations in their social structure, large housing estates in Łódź are also undergoing spatial, functional and morphological changes. One of the most important changes in the functional structure is the gradually increasing share of commercial areas (especially trade, services, offices, banks) at the expense of other non-commercial functions and functions with a lower level of financial profit (culture, education, housing), in the literature referred to as commercialization (Matlovič et al. 2001). This process is carried out mainly by filling the existing development with new buildings for commercial and service 
functions, and to a lesser extent by changes in the function of existing buildings.

In the studied housing estates a large number of new service centres (branches of banks, private medical clinics, beauty salons, etc.), large commercial buildings (including those of large retail chains such as Tesco, Carrefour, Biedronka, Lidl, Intermarché) have been created in the past two decades, but also local shopping malls (e.g. 'Galeria Retkińska' in Retkinia built in 2009, or 'Galeria Widzewska' in Widzew-Wschód built in 2011). As a result of this process, there emerged numerous catering facilities (bars, restaurants, pubs, cafes), and other places of leisure (fitness clubs, gyms, dance schools, etc).

The discussed process, most intense in the 1990s - still continues today, but its rate in the second decade after transformation has significantly decreased (Tab. 4). built on undeveloped areas intended in the design phase of estates for recreational areas or social services that were never realized.

The process of rapid growth in the number of commercial and non-commercial service facilities is accompanied by their spatial deconcentration. This increases their spatial availability and significantly improves the standard of living in the large housing estates. As a result of this process, changes are taking place in the social sphere. In large housing estates there are many new jobs and new places of leisure, previously absent there. The possibility of satisfying most of the needs (not just basic) in the limited space of estate without the necessity of commuting to the city centre has changed the daily routine of the inhabitants.

The spatial and functional changes discussed occur mainly as a result of the trans-

Table 4. The number of commercial buildings in Widzew-Wschód housing estate in Łódź

\begin{tabular}{|l|c|c|r|}
\hline \multicolumn{1}{|c|}{ The type of building } & The end of 1980s & The end of 1990s & 2009 \\
\hline Detached commercial buildings & 8 & 115 & 139 \\
Residential buildings integrated with a commercial function & 27 & 75 & 85 \\
\hline
\end{tabular}

Source: based on Masica and Milewska (2003) elaboration and own field research.

Another non-commercial dimension of the functional transformation of large estates in transition is to fill the existing buildings by new sacred buildings, in the literature referred as the sacralisation of space (Matlovic 2000). The majority of the churches whose construction started in Łódź after 1989, are located in large housing estates (17 out of 25). Moreover, among 22 new parishes, set up after 1989, 15 have been in large housing estates ${ }^{6}$. The construction of a church is not always accompanied by the establishment of a new parish, and vice versa. Currently 24 churches are located in the surveyed housing estates, of which as many as 11 were built after 1989, and 7 currently under construction (Klima 2009). The churches are

\footnotetext{
6 The construction of a church is not always accompanied by the establishment of a new parish, and vice versa.
}

formation of large pieces of undeveloped land located in these estates. During the socialist period these areas were undeveloped mainly due to the incomplete implementation of the primary architectural and urban planning assumptions, which included providing a social infrastructure and services. Starting from the 1990s, these areas are transformed into parks, sports fields (mainly in the neighbourhood of schools), playgrounds, recreational areas and other meeting places. On these areas churches and new commercial and residential buildings are found.

Observations show that these changes are taking place mainly in the newer housing estates established in the second half of the 1970s and later. This is mostly because of the availability of free land and lower housing densities than in the older housing estates, but also because of the characteristics of the communities living there: the age structure, 
household structure and socio-economic status of inhabitants, which create specific needs and create a demand for specific forms of spatial development and amenities on the estate. The concentration of these changes is also affected by the large population, its potential customers or users.

In addition to these processes, large housing estates are experiencing physiognomic transformations. These like previous ones, are mainly taking place in the newer estates (types 2 and 3), and include:

- makeovers of housing building facades (richer colours help overcome the drabness of concrete deserts), predominantly following thermo-insulation investment projects;

- diversification of the monotonous landscape of the estates and the uniform appearance of the buildings due to the construction of new residential and commercial buildings, and the introduction of mini-architectural elements and architectural details;

- improvement in the technical condition of buildings (window replacements, refurbishment of stairwell entrances);

- improvement in maintenance of local greenery, but also concurrent reductions in area in favour of parking lots;

- introduction of elements that facilitate better spatial orientation (building markings);

- improvement in the state of maintenance of recreational areas (parks, playgrounds, pitches).

These processes, which include spatial and functional changes and changes in physiognomy of large housing estates, are both planned and spontaneous. They are caused both by the market processes in urban space and by planned activities aimed at improving the quality of life in these areas. The main actors are both developers offering new flats and entrepreneurs operating on the service market, the organisations administering housing resources in the estates (housing cooperatives and home-owner associations), as well as the city or local authorities. The most important group are the inhabitants themselves who are settling into new flats, buying primary 'old' flats and who initiate improvements in the local environment.

These changes, if coordinated and planned, help to make the estates into more friendly housing environments and improve their public perception, especially among their inhabitants. Unfortunately, it happens that sometimes these changes are chaotic and random, and do not contribute to an improvement in the estates' appearance. The main weaknesses of the these changes are insufficient scope, chaos, and lack of coordination, as well as a lack of financial support from the state or involvement on the part of the inhabitants.

\section{Conclusions}

The research has provided evidence that the large housing estates in Łódź classified into three types that vary by the period of their construction, not only differ in the size of the dwellings they offer and the socio-demographic structure of their inhabitants, but also by the rate of the changes which take place in these estates.

Also, it has been found that in recent years the large housing estates in Łódź have been undergoing numerous transformations, which include:

- the ageing of the population, the growth in number of one-person households, the decrease in percentage of working people and the increase in level of education, which coincide with changes observed in the entire city and differ in particular estates depending on the time of their construction. These processes are not specific for large housing estates, nor for Łódź, because they occur in other large cities in Poland and are associated with global demographic trends (the second demographic transition);

- the intensification of housing development, which takes the form of individual multi-family buildings or complexes, characterized by a higher standard and distinctive physiognomy (architectural detail, the colour and shape of the buildings), and 
which results in an inflow of new residents and the formation of enclaves of a higher socio-economic status within the estate space. These processes lead to an increase in the socio-spatial diversification of these estates;

- commercialization caused primarily by supplementing existing commercial buildings with new ones, as well as by changing the functions of others. These processes improve access to shopping and services and reduce their spatial concentration, as well as help overcome the mono-functional nature of the estates. As a result, the social sphere of the housing estates is changing, new jobs appear, and new places and new forms of spending leisure time. The daily routine of the inhabitants changes as well, because satisfying the majority of needs (not only basic ones) may take place within the estate space and does not require commuting to the city centre. In consequence of these changes, the inhabitants' living conditions have improved;

- space sacralisation, which takes place by emergence of new sacred buildings (only Catholic churches), the construction of which was severely restricted in socialist times;

- improvement in the physiognomy of buildings (by modernization of their facades), and the improvement in quality of public and semi-public spaces among blocks of flats. These spaces undeveloped during the socialist period, after 1990 were turned into new parks, playgrounds, sports fields, and other greenery and recreation areas. These processes on the one hand, if planned and coordinated, improve the appearance of buildings and entire estates, but on the other hand, if chaotic and uncoordinated, not only do not help to beautify the space, but rather bring architectural and spatial disorder.

Taking into consideration the transformation processes of large housing estates described by Matlovič and Sedláková (2007) it can be concluded that in examined estates occur the processes of revitalisation, commercialization, sacralisation, and initial form of segregation. However, the symptoms of downgrading of socio-economic status were not found.

The observed changes in the functional and spatial structure occurred both as a result of market processes (the commercialization and intensification of housing developments by private investors), and as a result of political changes (sacralisation), as well as a result of intentional efforts to improve the quality of life in large housing estates through their modernization (improvement of the layout of existing 'old' buildings and the redevelopment of public and semi-public spaces between them). Observations confirm that transformations in the functional and spatial structure are more advanced in newer estates (types 2 and 3).

The research findings inspire the reflection that it is necessary to verify opinions, presented in literature and shared by many researchers (see the introduction), that in cities after the systemic transformation, large housing estates will become similar to those in Western Europe. It seems rather that the estates in post-socialist cities will undergo changes according to their own scenarios. The situation in Łódź, a city with a high percentage of pre-war, substandard housing resources and relatively low wealth levels, produces circumstances in which a flat located in large housing estate is still an attractive place of residence. Considering the three scenarios developed by Temelova et al. (2011), can be assumed that the large housing estates in Łódź have positive prospects for future development thanks to the mixed socio-economic composition of inhabitants and the improving physical condition of the residential environment.

The opinion that large housing estates are problem areas is not confirmed in Łódź the third largest city in post-socialist Poland. In the analysed housing estates the symptoms of physical or social degradation were not found. Moreover, processes found there contribute to the prevention of the nega- 
tive phenomena leading to the degradation of these areas, referred to as the 'large housing estate syndrome' identified in many estates in Western Europe.

\section{References}

BERNT M., 2007. Neither normalisation. nor decay: Housing estates in Eastern Germany. [in:] B. Komar, B. Kucharczyk-Brus (eds.), Housing and environmental conditions in post-communist countries, Gliwice: Wydawnictwo Politechniki Śląskiej, pp. 41-55.

Borén T., GENTILE M., 2007. Metropolitan processes in post-communist states: an introduction. Geografiska Annaler. Series B. Human Geography, vol. 89, no. 2, pp. 95-110.

BorowIK I., 2003. Blokowiska - miejski habitat w ogladzie socjologicznym. Wrocław: Arboretum, $170 \mathrm{pp}$.

Chmielewski J.M., MiReCKA M., 2001. Modernizacja osiedli mieszkaniowych. Warszawa: Oficyna Wydawnicza Politechniki Warszawskiej, 273 pp.

Coudroy de Lille L., 2000. Jak dalece można porównywać miasta europejskie? Refleksje nad procesami i pojęciami na przykładzie osiedli mieszkaniowych we Francji w Polsce. [in:] I. Jażdżewska (ed.), Miasto postsocjalistyczne organizacja przestrzeni miejskiej jej przemian. XIII Konwersatorium Wiedzy o Mieście, Łódź: Wydawnictwo UŁ, pp. 99-112.

CZEPCZYŃSKI M., 1999. Rozwój i upadek koncepcji osiedli blokowych. Biuletyn KPZK PAN, no. 190, Warszawa: Komitet Przestrzennego Zagospodarowania Kraju PAN, pp. 49-67.

DekKer K., de Vos S., Musterd S., van Kempen R., 2011. Residential satisfaction in housing estates in European cities: a multi-level research approach. Housing Studies, vol. 26, no. 4, pp. 479-499.

Dekker K., Hall S., van Kempen R., Tosics I., 2005. Restructuring large housing estates in European cities: An introduction. [in:] R. van Kempen, K. Dekker, S. Hall, I. Tosics (eds.), Restructuring large housing estates in Europe, Bristol (UK): Policy Press, pp. 1-17.

Dekker K., Musterd S., van Kempen R., 2007. Explaining differentials in housing and neigh-
Editors' note:

Unless otherwise stated, the sources of tables and figures are the author(s), on the basis of their own research.

bourhood satisfaction in post-WWII large housing estates in European cities. [in:] European Network for Housing Research (ENHR) conference, Rotterdam, pp. 15-28.

ENYEDI G., 1998. Transformation in central European postsocialist cities. [in:] G. Enyedi (ed.), Social change and urban restructuring in Central Europe, Budapest: Akademiai Kiadó, pp. 9-34.

Gaczek W., Rykiel Z., 1999. Nowe lokalizacje mieszkaniowe w przestrzeni miasta. Biuletyn KPZK PAN, no. 190, Warszawa: Komitet Przestrzennego Zagospodarowania Kraju PAN, pp. 29-47.

GorcZYCA K., 2009. Wielkie osiedla mieszkaniowe - diagnoza stanu obecnego. podejmowane działania rewitalizacyjne. [in:] W. Jarczewski (ed.), Przestrzenne aspekty rewitalizacji, Kraków: Instytut Rozwoju Miast, pp. 89-123.

Groeger L., 2004. Waloryzacja przestrzeni mieszkaniowej w opiniach klientów łódzkich biur obrotu nieruchomościami. Łódź: Wydawnictwo Uniwersytetu Łódzkiego, 126 pp.

Grossmann K., HaAse A., 2011. Brick or block - housing preferences and the urban fabric. Residential change and demographic challenge. [in:] A. Haase, A. Steinfüher, S. Kabisch, K. Grossmann, R. Hall (eds.), Residential change and demographic challenge: The inner city of East Central Europe in the 21st century, Burlington: Ashgate, pp. 255-275.

GórczyńsKa M., 2008. Percepcja i waloryzacja osiedla mieszkaniowego (na podstawie badań prowadzonych w Warszawie w ramach projektu RESTATE). Przegląd Geograficzny, vol. 80, no. 2, pp. 267-286.

JAŁOWIECKI B., 1995. Miasto polskie - między utopiq a rzeczywistościq. [in:] P. Starosta (ed.), Zbiorowości terytorialne i więzi społeczne, Łódź: Wydawnictwo Uniwersytetu Łódzkiego, pp. 36-43.

JenCKS CH., 1977. The language of post-modern architecture. London: Academy Editions, 152 pp.

KLIMA E., 2009. Łódzkie kościoły katolickie po 1989 roku.[in:] I.Jażdżewska(ed.),XXII Konwersatorium 
Wiedzy o Mieście. Duże i średnie miasta polskie w okresie transformacji, Łódź: Wydawnictwo Uniwersytetu Łódzkiego, Łódzkie Towarzystwo Naukowe, pp. 267-279.

KNorr-Siedow T., 1996. Present and future outlook for large housing estates. Berlin: European Academy of the Urban Environment, http:// www.eaue.de/Housing/housfut.htm [6 February 2014].

Kotus J., 2006. Changes in the spatial structure of a large Polish city - the case of Poznań. Cities, vol. 23, no. 5, pp. 364-381.

Kovács Z., 1999. Cities from state-socialism to global capitalism: An introduction. GeoJournal, no. 49, pp. 1-6.

KovÁcs Z., Herfert G., 2012. Development pathways of large housing estates in post-socialist cities: an international comparison. Housing Studies, vol. 27, no. 3, pp. 324-342.

KovÁcs Z., Herfert G., Wiest K., 2010. Changing housing preferences and residential mobility in post-socialist cities - the position of large housing estates. Prague: ENHR Conference in Prague 2009, http://www.enhr2009.com/enhr/info/ cz/25132/W18.html [6 February 2014].

KozŁoWSKI S., 2005. Pozytywne przykłady modernizacji osiedli mieszkaniowych. [in:] I. Jażdżewska (ed.), XVIII Konwersatorium Wiedzy o Mieście. Współczesne procesy urbanizacji $i$ ich skutki, Łódź: Wydawnictwo Uniwersytetu Łódzkiego, pp. 341-350.

LEWICKA M., 2004. Identyfikacja z miejscem zamieszkania mieszkańców Warszawy: determinanty i konsekwencje. [in:] J. Grzelak, T. Zarycki (eds.), Społeczna mapa Warszawy, Warszawa: Scholar, pp. 273-315.

MARCIŃCZAK S., 2007. The socio-spatial structure of post-socialist Łódź. Poland. Results of national census 2002. Bulletin of Geography. Socioeconomic Series, no. 8, pp. 65-82.

MAsica R., Milewska K., 2003. Zmiany w zagospodarowaniu zespołu osiedli mieszkaniowych: przykład Widzewa-Wschodu w Łodzi. [in:] T. Marszał (ed.), Zagospodarowanie przestrzeni miejskiej Łodzi, Biuletyn KPZK PAN, no. 203, Warszawa: Komitet Przestrzennego Zagospodarowania Kraju PAN, pp. 29-44.

MATLOVIČ R., 2000. Sakralizacja - czastkowy proces transformacji przestrzeni miejskiej miasta postkomunistycznego na przykładzie Preszowa. [in:] I. Jażdżewska (ed.), Miasto postsocjalistycz- ne - organizacja przestrzeni miejskiej i jej przemiany. XIII Konwersatorium Wiedzy o Mieście, Łódź: Wydawnictwo Uniwersytetu Łódzkiego, Łódzkie Towarzystwo Naukowe, pp. 121-128.

Matlovič R., IRA V., SÝkora L., SzCzyrba Z., 2001. Procesy transformacyjne struktury przestrzennej miast postkomunistycznych na przykładzie Pragi, Bratysławy, Ołomuńca oraz Preszowa. [in:] I. Jażdżewska (ed.), Miasto postsocjalistyczne - organizacja przestrzeni miejskiej i jej przemiany. XIV Konwersatorium Wiedzy o Mieście, Łódź: Wydawnictwo Uniwersytetu Łódzkiego, Łódzkie Towarzystwo Naukowe, pp. 243-252.

Matlovič R., Sedláková A., 2007. Transformation processes of the urban space in postcommunist cities. [in:] M. Malikowski, S. Solecki (eds.), Przemiany przestrzenne w dużych miastach Polski i Europy Środkowo-Wschodniej, Kraków: Nomos, pp. 32-46.

Murie A., Knorr-Siedow T., van Kempen R., 2003. Large housing estates in europe: General development and theoretical backgrounds. RESTATE, report 1, Utrecht: Utrecht University, 61 pp.

Musterd S., van Kempen R., 2005. Large-scale housing estates in european cities: opinions of residents on recent developments. RESTATE, report 1, Utrecht: Utrecht University, 118 pp.

Rembarz G., 2010. Rola przestrzeni publicznej w odnowie i kształtowaniu miejskiego środowiska mieszkaniowego. [in:] P. Lorens, J. Martyniuk-Pęczek (eds.), Zarządzanie rozwojem przestrzennym miast. Seria Miasto-Metropolia-Region, Gdańsk: Wydawnictwo Urbanista, Akapit-DTP, pp. 138-156.

RęBOWSKA A., 2000. Rehabilitacja blokowisk. [in:] Z. Ziobrowski, D. Ptaszycka-Jackowska, A. Rębowska, A. Geissler (eds.), Odnowa miast. Rewitalizacja, rehabilitacja, restrukturyzacja, Kraków: Instytut Gospodarki Przestrzennej i Komunalnej, pp. 85-105.

RęBOWSKA A., JeżAK J., RydzIK W., WęGŁOWSKI M., 2006. Strategie rehabilitacji "blokowisk”. Kraków: Instytut Rozwoju Miast, 129 pp.

RYKIEL Z., 1999. Przemiany struktury społeczno-przestrzennej miasta polskiego a świadomość terytorialna jego mieszkańców. Prace Geograficzne, vol. 170, Warszawa: Instytut Geografii i Przestrzennego Zagospodarowania PAN, $148 \mathrm{pp}$.

SÝKORA L., 2009. Post socialist cities. [in:] R. Kitchin, N. Thrift (eds.), International Encyclopedia 
of Human Geography, vol 8, Oxford: Elsevier, pp. 387-395.

SZAFRAŃSKA E., 2009. The residential attractiveness of large housing estate in the opinion of inhabitants. The case of Retkinia North housing estate in Lodz. [in:] S. Kabisch (ed.), Vulnerability, risk and complexity: Impacts of global change on human habitats, Leipzig: Helmholtz Centre For Environmental Research (UFZ), pp. 110-112.

SZAFRAŃSKA E., 2011. Changes in socio-spatial structure of large housing estates on postsocialist Łódź (Poland). Architecture Civil Engineering Environment, vol. 4, no. 1, pp. 25-32.

SzAfrańska E., 2012a. Przemiany struktury spotecznej, przestrzennej i funkcjonalnej wielkich osiedli mieszkaniowych na przykładzie osiedla Widzew-Wschód w Łodzi. [in:] J. Dzieciuchowicz (ed.), The contemporary transformation of the housing environment - selected problems, Space-Society-Economy, no. 11, Łódź: University of Łódź. Department of Spatial Economy and Spatial Planning, pp. 179-195.

SzAFRAŃSKA E., 2012b. Gentryfikacja wielkich osiedli mieszkaniowych w mieście postsocjalistycznym - nowe zjawisko czy nadużycie terminologiczne? [in:] J. Jakóbczyk-Gryszkiewicz (ed.), Procesy gentryfikacji w mieście. XXVI Konwersatorium Wiedzy o Mieście, Łódź: Wydawnictwo Uniwersytetu Łódzkiego, pp. 153-167.

SZAFRAŃSKA E., 2013. Large housing estates in post-socialist Poland as a housing policy challenge. European Spatial Research and Policy, vol. 20, no. 1, pp. 119-129.

SzelÉNYI I., 1996. Cities under socialism - and after. [in:] G. Andrusz, M. Harloe, I. Szelényi (eds.), Cities after socialism. Urban and regional change and conflict in post-socialist societies, Oxford: Blackwell Publishers, pp. 286-317.

Szelényl I., KonRÁd G., 1969. Sociological problems of new housing estates. Budapest: Akademiai Kiadó, 212 pp.

Temelová J., Novák J., OuŘedníček M., Puldová P., 2011. Housing estates in the Czech Republic after socialism: Various trajectories and inner differentiation. Urban Studies, vol. 48, no. 9, pp. 1811-1834.
Turkington R., van Kempen R., Wassenberg F. (eds.), 2004. High-rise housing in Europe: Current trends and future prospects. Delft: Delft University Press, 284 pp.

Warchalska-Troll A., 2012. How to measure susceptibility to degradation in large postsocialist housing estates? Prace Geograficzne, no. 130, Kraków: Instytut Geografii i Gospodarki Przestrzennej Uniwersytetu Jagiellońskiego, pp. 55-71.

Wassenberg F., Turkington R., van Kempen R., 2004a. High-rise housing estates in Europe. [in:] R. Turkington, R. van Kempen, F. Wassenberg (eds.), High-rise housing in Europe: current trends and future prospects, Delft: Delft University Press, pp. 1-14.

Wassenberg F., Turkington R., van Kempen R., 2004b. Prospects for high-rise housing estates. [in:] R. Turkington, R. van Kempen, F. Wassenberg (eds.), High-rise housing in Europe: current trends and future prospects, Delft: Delft University Press, pp. 265-280.

WęCŁawowicz G., 2007. Geografia społeczna miast. Warszawa: Wydawnictwo Naukowe PWN, 224 pp.

WęcŁaWOWICZ G., Guszcza A., KozŁoWsKI S., Bielawska A., Adamiak A., Krasowska M., FadER A., BIERZYŃSKI A., 2005. Large housing estates in Poland: Opinions of residents on recent developments. RESTATE, report 4k, Utrecht: Utrecht University, 90 pp.

Węctawowicz G., KozŁowski S., Bajek R., 2003. Large housing estates in Poland: Overview of developments and problems on Warsaw. RESTATE, report 2f, Utrecht: Utrecht University, $74 \mathrm{pp}$.

ZBOROWSKI A., 2005. Przemiany struktury społeczno-przestrzennej regionu miejskiego $w$ okresie realnego socjalizmu i transformacji ustrojowej (na przykładzie Krakowa). Kraków: Instytut Geografii i Gospodarki Przestrzennej Uniwersytetu Jagiellońskiego, 576 pp. 
http://rcin.org.pl 